\title{
First record of Dichelyne (Dichelyne) bonacii (Nematoda, Cucullanidae) parasitizing the intestine of two species of lutjanid fish (Perciformes, Lutjanidae) on the northeast Brazilian coast
}

\author{
ANDRÉ M. ALVES ${ }^{1}$, TAÍSSA A.S. CALASSANS ${ }^{2}$, JANAÍNA F. FREIRE ${ }^{1}$, GEZA T.R. E SOUZA ${ }^{3}$, RICARDO \\ M. TAKEMOTO ${ }^{4}$, CLAUDIA M. DE MELO ${ }^{2}$, VERÓNICA L.S. JERALDO ${ }^{2}$ and RUBENS R. MADI ${ }^{1}$
}

\begin{abstract}
${ }^{1}$ Programa de Pós-graduação em Saúde e Ambiente, Laboratório de Biologia Tropical, Instituto de Tecnologia e Pesquisa, Universidade Tiradentes, Av. Murilo Dantas, 300, 49032-490 Aracaju, SE, Brazil

${ }^{2}$ Programa de Pós-graduação em Saúde e Ambiente, Laboratório de Doenças Infecciosas e Parasitárias, Instituto de Tecnologia e Pesquisa, Universidade Tiradentes, Av. Murilo Dantas, 300, 49032-490 Aracaju, SE, Brazil ${ }^{3}$ Instituto Federal de Educação, Ciência e Tecnologia de São Paulo, Av. Prof. Célso Ferreira da Silva, Jardim Europa II, Avaré, 18707-150 São Paulo, SP, Brazil

${ }^{4}$ Núcleo de Pesquisas em Limnologia, Ictiologia e Aquicultura, Laboratório de Ictioparasitologia, Universidade Estadual de Maringá, Av. Colombo, 5790 - Vila Esperanca, 87020-900 Maringá, PR, Brazil
\end{abstract}

Manuscript received on May 15, 2019; accepted for publication on August 15, 2019

\begin{abstract}
How to cite: ALVES AM, CALASSANS TAS, FREIRE JF, SOUZA GTR, TAKEMOTO RM, MELO CM, JERALDO VLS AND MADI RR. 2019. First record of Dichelyne (Dichelyne) bonacii (Nematoda, Cucullanidae) parasitizing the intestine of two species of lutjanid fish (Perciformes, Lutjanidae) on the northeast Brazilian coast. An Acad Bras Cienc 91: e20190544. DOI 10.1590/0001-3765201920190544.
\end{abstract}

\begin{abstract}
Lutjanids are marine fish and commonly inhabit coral reefs, which have migratory habits and feed in a general way, due to these characteristics, are susceptible to infections by parasites, such as cuculanid nematodes. This work aimed to report for the first time, the occurrence of Dichelyne (Dichelyne) bonacii in Brazil, in two new hosts, Lutjanus analis and Rhomboplites aurorubens, acquired from local artisanal fishermen at the Aracaju city public fishing terminal ( $10^{\circ} 54^{\prime} 17^{\prime \prime} \mathrm{S} 37^{\circ}{ }^{\prime}$ ' $56^{\prime}$ " $\left.\mathrm{W}\right)$, northeast coast of Brazil. Adult nematodes were collected from the intestinal tract of the hosts, clarified in Aman's Lactophenol and were briefly described here. Three adult males and five gravid females were found, indicating that the two species of fish acted as definitive hosts. Currently, this species of parasite has been reported only from fish collected in the coast of Mexico, which makes this work the first record of this parasite in Brazilian coastal waters. The results show that probably the range of hosts and the distribution of $D$. (Dichelyne) bonacii is not as restricted as data pointed in the literature, being a little wider, extending also to waters that bathe the Brazilian coast.
\end{abstract}

Key words: Brasil, Cucullanidae, Lutjanus, Nematoda.

Lutjanids are predominantly marine fish, cosmopolitan, migratory and general carnivorous. In the northeast of Brazil, the fish of the Lutjanidae

Correspondence to: André Mota Alves

E-mail: andremta@outlook.com

ORCid: https://orcid.org/0000-0002-9150-5287 family are commercially exploited because of the quality of their meat, being an important food source (Allen 1985, Frédou and Ferreira 2005, Begossi et al. 2011). Due to the biology of the lutjanids, they are susceptible to infections by certain groups of parasites, such as cuculanid nematodes, and 
because they have economic importance, it is essential to know their parasitic fauna. In this sense, the present work aims to report the first occurrence of Dichelyne (Dichelyne) bonacii in Brazilian territory, with the addition of two new fish to the list of hosts.

Fishes were purchased according to availability at the public fishing terminal of Aracaju (10 ${ }^{\circ} 54^{\prime} 17^{\prime \prime S} 37^{\circ} 2$ ' $56^{\prime}$ ” W) from local fishermen. Fishes were properly stored and transported to the laboratory, where they were identified as Lutjanus analis Cuvier, 1828 (69 specimens analyzed) and Rhomboplites aurorubens Cuvier, 1829 (1 specimen analyzed) according to Allen (1985). The parasitological procedures were done according to Eiras et al. (2006) that revealed the presence of nematodes identified as Dichelyne bonacii Gonzalez-Solis, Arqaez-Garcia \& GuillenHernandez, 2002 (Nematoda: Cucullanidae). The nematodes found were clarified in Aman 's Lactophenol. Illustrations were prepared optical microscope with camera lucida and edited using the software Paint. Net. V4.0.9 and GIMP 2.10. Biometry of the specimens was performed using a light microscope (Coleman Model: N-120 Fuse T2A) coupled to a camera (HDCE-X5 model) and to a computer with Scope Image 9.0 (X5) software. Values were expressed in millimeters $(\mathrm{mm})$.

Cucullanidae Cobbold, 1864

Dichelyne Jägerskiöld, 1902

Dichelyne bonaci Gonzalez-Solis, ArqaezGarcia \& Guillen-Hernandez, 2002

General description: Based on 3 gravid females and 2 adult males. Body elongated and robust, females clearly larger than males (Figure 1a, b), whitish, very thick cuticle and with transverse striae more evident in the posterior region and tail. A rounded anterior end with a slit-shaped mouth, surrounded by two pairs of papillae (two dorsallateral and two ventro-lateral) and a pair of lateral aphids (Figure 1c). Oesophagus expanded at both ends; the anterior region is formed by a well developed large pseudobucal capsule with internal cuticular coating (Oesophastome). Large deirids, located near the posterior region of the esophagus (Figure 1a, I). Elliptical ventricle, lobed. Excretory pore located at the level of the ventricle (Figure 1a, II). Nerve ring slightly posterior to the pseudobucal capsule (Figure 1b, I). The oesophagus opens into the intestine, dividing it into two previously projected intestinal cecums, not reaching the level of the nerve ring. Tail of both sexes conical, with pointed mucron.

Male (Based on 2 specimens). Body length $11.2( \pm 0.84) \mathrm{mm}$ (clearly smaller than females); Maximum width $0.59( \pm 0.10) \mathrm{mm}$; Length of oesophagus $0.87( \pm 0.02) \mathrm{mm}$, occupying $7.76 \%$ of body length; Length and width of the ventricle $0.07(0.01) \mathrm{mm} \times 0.11( \pm 0.01) \mathrm{mm}$. They have 11 pairs of caudal papillae, 6 pre-cloacal, 2 adcloacal and 3 post-cloacal (Figure 1d, I). Three previous pre-cloacal subventral pairs, with first pair slightly anterior to the second and third pairs. Bulging deirids located near the posterior region of the esophagus. Two pairs of subventral adcloacal papillae. Distinguishing papilla present in the anterior cloacal lip. Three pairs of postcloacal papillae, one lateral, one subdorsal and one subventral. Spicules are alate, similar in shape and size, but the left spicule is longer than the right. Length of right spine $0.45( \pm 0.64) \mathrm{mm}$, occupying $4.01 \%$ of body length; length of the left spike 0.65 ( \pm 0.11 ), occupying $5.80 \%$ of body length. Ventral sucker absent. Gubernaculum in the form of "Y" (Figure 1f), length $0.11 \mathrm{~mm}( \pm 0.002) \mathrm{mm}$. Tail length $0.19( \pm 0.01) \mathrm{mm}$.

Female (Based on 2 specimens): Body length $13.4( \pm 0.28) \mathrm{mm}$ (markedly larger than males); Maximum width $0.75( \pm 0.02) \mathrm{mm}$ (wider than males); Length of esophagus $1.15( \pm 0.03) \mathrm{mm}$, occupying $8.58 \%$ of body length; Length and width of the ventricle $0.04( \pm 0.007) \mathrm{mm} \times 0.09$ $( \pm 0.002) \mathrm{mm}$. Opening of the vulva in the anterior region of the body, in the central region between 


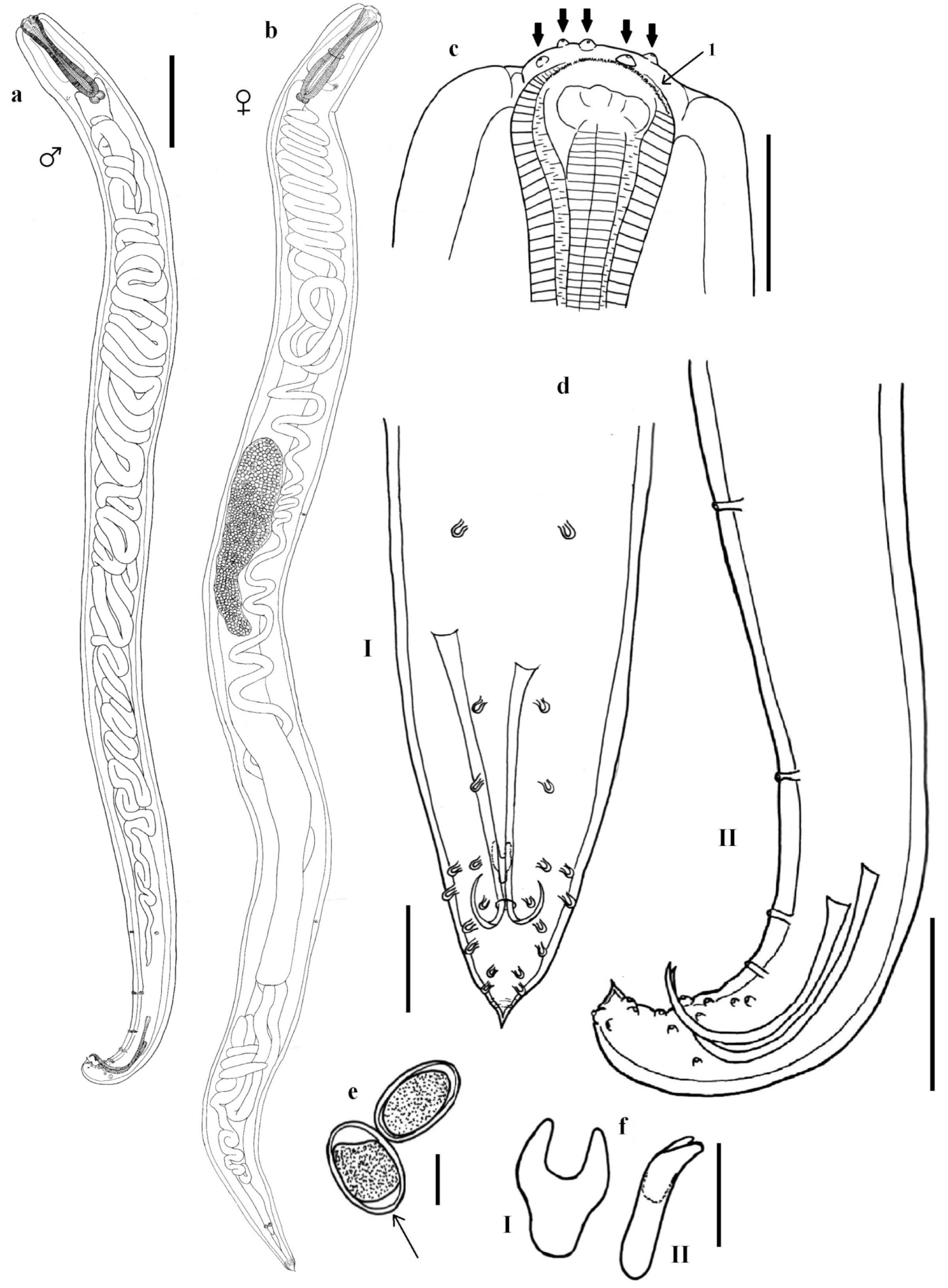

Figure 1 - Dichelyne bonacii collected from Lutjanidae of the northeast coast of Brazil. a - Male side view, IDeirids; II - excretory pore; b - female ventral view, bar: 1mm; I-Nervous ring; II- Opening of the vulva; c - Anterior region, with labial papillae (smaller arrows); I- small serrated teeth of the mouth, bar: $0.5 \mathrm{~mm}$; $\mathbf{d}$ - I - ventral view of the posterior region of the male, showing the arrangement of the caudal papillae, bar: $0.1 \mathrm{~mm}$; II- lateral view of the posterior region of the male, bar: $1 \mathrm{~mm}$; Eggs, bar: $0.01 \mathrm{~mm}$; $\mathrm{f}-$ Gubernculum, ventral (I) and lateral (II) vision, bar: $0.05 \mathrm{~mm}$; g- Winged spikes of the male, bar: $0.5 \mathrm{~mm}$. 
the nerve ring and the ventricle. Uterus containing numerous eggs, some with non-cleaved content. Elliptic eggs, thin and double coating (Figure 1e, arrow indicates). Tail length $0.30( \pm 0.01)$.

Host: Lutjanus analis (1 fish infected) Prevalence: $1.44 \%$, Mean intensity: $3.00( \pm 0.00)$; Rhomboplites aurorubens (1 fish infected) Prevalence: 100\%; Average intensity: $5.00( \pm 0.00)$.

Infection site: Intestine of both hosts.

Location: Northeastern coast of Brazil, Aracaju, SE.

The parasites found were adults ( 3 Males and 5 gravid females), which suggests that the fish acted as definitive hosts. The characteristics previously described, especially in relation to the instestine with 2 intestinal cecums, to the arrangement of caudal papillae and the absence of a ventral "sucker", allowed identification as D. bonacii. Five other species of the genus Dychelyne have been described in the gut of other fish of families such as Sciaenidae, Gobiidae, Haemulidae, Pleuronectidae, Serranidae and Lutjanidae, in localites as Argentina, New Caledonia (Southern Pacific Ocean), China (Guangdong Province and region Leste), Iran (Persian Gulf), Southeastern Brazil (Coast of Rio de Janeiro), Northeast Atlantic, Western Mediterranean and South America (Atlantic Coast) (Timi et al. 2009, Moravec and Justine 2011, Li et al. 2014a, b, Moravec et al. 2014, Paschoal et al. 2014, Isbert et al. 2015).

Cuculanids in the adult stage are intestinal parasites of vertebrates, and although the life cycle of many of their species is not yet known (Pereira Jr. et al. 2002), they are widely distributed in a wide variety of fish (marine and sweet) and are transmitted via the trophic chain (GonzálezSolis et al. 2002, Anderson et al. 2009, Moravec and Justine 2011, Li et al. 2014a). The species Lutjanus analis and $R$. aurorubens are fish without food restriction, probably the specimens have become infected through the ingestion of organisms already infected by the parasite, such as crustaceans, molluscs and smaller fish (Pereira Jr. et al. 2002). Originally the parasite was described by González-Solís et al. (2002), collected from Mycteroperca bonaci and L. griseus in the Yucatan peninsula, Mexico. The most recent records of this species of parasite were made occurring in $L$. griseus, M. bonaci and Ocyurus chrysurus, in the region of Yucatán, México (original region of the description of the parasite), extending to the region of Veracruz (Argáez-García et al. 2010, EspínolaNovelo et al. 2013, Montoya-Mendoza et al. 2014), demonstrating that there were already an extensive geographic distribution. The occurrence of the parasite in the Brazilian coast can be explained by the migratory habits and the distribution that $L$. analis and $R$. aurorubens have, from the Western Atlantic: USA (Massachusetts, Florida, Bermuda and North Carolina), Gulf of Mexico, Caribbean Sea, Southeastern Brazil (São Paulo) to the West Indies (FishBase 1999a, b). Thus, the distribution of $D$. bonacii appears to be somewhat broader than the records pointed out in the literature. This is the first record of occurrence of this cuculanid in Brazil, in addition, L. analis and $R$. aurorubens are registered as new hosts in the biological cycle of this parasite. This information becomes important to better understand the distribution of this species of parasite in marine fish.

\section{AUTHOR CONTRIBUTIONS}

AMA: Study planning, data collection and Manuscript preparation (Writing and Illustrations). Obtaining, analyzing and interpreting data. TASC: Study planning and Manuscript preparation. Final revision of the manuscript. JFF: Study planning, data collection and manuscript preparation. Obtaining, analyzing and interpreting data.GTRS: Study planning. Analysis and interpretation of data. Approval of the final version. RMT: Study planning and preparation of the manuscript. Analysis and interpretation of data. Approval of the final version. 
CMM: Study planning and preparation of the manuscript. Approval of the final version. VLSJ: Study planning and preparation of the manuscript. Approval of the final version. RRM: Study planning and preparation of the manuscript. Approval of the final version.

\section{REFERENCES}

ALLEN GR. 1985. FAO species catalog. Snappers of the world: An annotated and illustrated catalogue of lutjanid species known to date. FAO Fisheries Synopsis. 6, 208 p.

ANDERSON RC, CHABAUD AG AND WILLMOTT S. 2009. Keys to the nematode parasites of vertebrates. [Archival volume.] Wallingford (U.K.): CAB International, $463 \mathrm{p}$.

ARGÁEZ-GARCÍA N, GUILLÉN-HERNÁNDEZ S AND AGUIRRE-MACEDO ML. 2010. Intestinal helminths of Lutjanus griseus (Perciformes: Lutjanidae) from three environments in Yucatán (Mexico), with a checklist of its parasites in the Gulf of Mexico and Caribbean region. Rev Mex Biodivers 81: 903-912.

BEGOSSI A, SALIVONCHK SV, ARAUJO LG, ANDREOLI TB, CLAUZET M, MARTINELLI CM, FERREIRA AGL, OLIVEIRA LEC AND SILVANO RAM. 2011. Ethnobiology of snappers (Lutjanidae): target species and suggestions for management. J Ethnobiol Ethnomed 7(11): $1-22$.

EIRAS JC, TAKEMOTO RM AND PAVANELLI GC. 2006. Métodos de estudo e técnicas laboratoriais em parasitologia de peixes. Maringá: Eduem, 199 p.

ESPÍNOLA-NOVELO JF, GONZÁLEZ-SALAS C, GUILLÉN-HERNÁNDEZ S AND MACKENZIE K. 2013. Metazoan parasites of Mycteroperca bonaci (Epinephelidae) off the coast of Yucatán, Mexico, with a checklist of its parasites in the Gulf of Mexico and Caribbean region. Rev Mex Biodivers 84: 1111-1120.

FRÉDOU T AND FERREIRA BP. 2005. Bathymetric trends of Northeastern Brazilian snappers (Pisces, Lutjanidae): Implications for the reef fishery dynamic. Braz Arch Biol Technol 48: 787-800.

FISHBASE. 1999a. FishBase 99 CD-ROM. ICLARM, Manila. Accessed April 25 $5^{\text {th }}, 2019$. (a).

FISHBASE. 1999b. FishBase 99 CD-ROM. ICLARM, Manila. Accessed April 25 $5^{\text {th }}, 2019$. (b).

GONZÁLEZ-SOLÍS D, ARGÁEZ-GARCÍA N AND GUILLÉN-HERNÁNDEZ，S. 2002. Dichelyne (Dichelyne) bonacii n. sp. (Nematoda: Cucullanidae) from the grey snapper Lutjanus griseus and the black grouper
Mycteroperca bonaci off the coast of Yucatán, Mexico. Syst Parasitol 53: 109-113.

ISBERT W, MONTERO FE, CARRASSÓN M AND GONZÁLEZ-SOLÍS D. 2015. Dichelyne (Cucullanellus) romani n. sp. (Nematoda: Cucullanidae) in notacanthid fishes from the Northeast Atlantic and Western Mediterranean. Syst Parasitol 91: 35-47.

LI L, DU LQ, XU Z, GUO YN, WANG SX AND ZHANG LP. 2014a. Morphological variability and molecular characterisation of Dichelyne (Cucullanellus) pleuronectidis (Yamaguti, 1935) (Ascaridida: Cucullanidae) from the flatfish Pleuronichthys cornutus (Temminck \& Schlegel) (Pleuronectiformes: Pleuronectidae) in the East China Sea. Syst Parasitol 87: 87-98.

LI L, XU Z AND ZHANG LP. 2014b. Morphological and molecular evidence for a new species of the genus Dichelyne Jagerskiold, 1902 (Ascaridida: Cucullanidae) from marine perciform fishes in the South China Sea. Syst Parasitol 89: 107-116.

MONTOYA-MENDOZA J, JIMÉNEZ-BADILLO ML AND SALGADO-MALDONADO G. 2014. Helminths of Ocyurus chrysurus from coastal reefs in Veracruz, Mexico. Rev Mex Biodivers 85: 957-960.

MORAVEC F AND JUSTINE JL. 2011. Cucullanid nematodes (Nematoda: Cucullanidae) from deep-sea marine fishes of New Caledonia, including Dichelyne etelidis n. sp. Syst Parasitol 78: 95-108.

MORAVEC F, KHOSHEGHBAL M AND PAZOOKI J. 2014. Dichelyne (Dichelyne) spinigerus sp. nov. (Nematoda: Cucullanidae) from the marine fish Otolithes ruber (Sciaenidae) off Iran and first description of the male of Philometra otolithi Moravec et Manoharan, 2013 (Nematoda: Philometridae). Acta Parasitol 59(2): 229-237.

PASCHOAL F, VIEIRA FM, CEZAR AD AND LUQUE JL. 2014. Dichelyne (Cucullanellus) tornquisti n. sp. (Nematoda: Cucullanidae) from Corocoro Grunt, Orthopristis ruber (Cuvier, 1830) (Perciformes: Haemulidae) from Southeastern Brazil. J Parasitol 100(2): 215-220.

PEREIRA JRJ, DA COSTA MAS AND VIANNA RT. 2002. Índices parasitológicos de cucullanidae (nematoda: seratoidea) em micropogonias furnieri (desmarest, 1823) no litoral do rio grande do Sul, Brasil. Atlântica 24(2): 97-101.

TIMI JT, LANFRANCHI AL, TAVARES LER AND LUQUE JL. 2009. A new species of Dichelyne (Nematoda, Cucullanidae) parasitizing sciaenid fishes from off the South American Atlantic coast. Acta Parasitol 54(1): 4552. 